\title{
Encouraging Minority Enrollment in IT Degree Programs through Participatory Organizations
}

\section{Theresa A. Steinbach, James D. White, and Linda V. Knight DePaul University, Chicago, Illinois USA}

\author{
tsteinbach@cti.depaul.edu jwhite@cti.depaul.edu Iknight@cti.depaul.edu
}

\begin{abstract}
Worldwide demand for qualified IT workers has employers exploring under-represented segments of the workforce. The percentage of women IT workers is not keeping pace with the growth of the industry. Minority populations, which are country specific, are also under-represented segments. This paper focuses on three significant minority segments in the United States: women, African Americans and Hispanic Americans. Studies have shown that increasing the number of these three groups enrolled in university computer science programs can help ease the shortage of qualified IT workers. One approach to attract and retain these students is to encourage the use of participatory organizations. This paper traces the initial efforts of one university to retain these segments through student-led chapters of the Association for Computing Machinery - Women, National Society of Black Engineers and Society of Hispanic Professional Engineers. Critical success factors are identified for use by other universities interested in initiating similar programs.
\end{abstract}

Keywords: minority, women, African American, Hispanic American, student organizations, computer science

\section{Background: IT Industry}

\section{United States}

Employment in the IT industry more than doubled from 626,600 in 1987 to 1.34 million in 1997 and this growth is projected to continue unabated. The U.S. Bureau of Labor Statistics' listing of the 10 fastest growing occupations 1998 - 2008 identifies the top five as IT-related (Table 1). The number of jobs in the IT sector is projected to nearly double adding 1.4 million new jobs and increasing the IT workplace to 2.9 million.

Material published as part of these proceedings, either on-line or in print, is copyrighted by Informing Science. Permission to make digital or paper copy of part or all of these works for personal or classroom use is granted without fee provided that the copies are not made or distributed for profit or commercial advantage AND that copies 1) bear this notice in full and 2) give the full citation on the first page. It is permissible to abstract these works so long as credit is given. To copy in all other cases or to republish or to post on a server or to redistribute to lists requires specific permission from the publisher at Publisher@InformingScience.org 


\begin{tabular}{|l|c|c|r|l|}
\cline { 2 - 5 } \multicolumn{2}{c|}{} & \multicolumn{2}{l}{ Employment } & \multicolumn{2}{l|}{ Change } \\
\hline Occupation & 1998 & 2008 & Number & Percent \\
\hline Computer engineers & 299,000 & 622,000 & 323,000 & 108 \\
\hline Computer support specialists & 429,000 & 869,000 & 439,000 & 102 \\
\hline Systems analysts & 617,000 & $1,194,000$ & 577,000 & 94 \\
\hline Database administrators & 87,000 & 155,000 & 67,000 & 77 \\
\hline Desktop publishing specialists & 26,000 & 44,000 & 19,000 & 73 \\
\hline Total & $1,458,000$ & $2,884,000$ & $1,425,000$ & 98 \\
\hline
\end{tabular}

Table 1. The top five fastest growing occupations, 1998 - 2008 (U.S. Bureau of Labor)

In light of these projections, questions have surfaced about the supply of workers to fill these new jobs. Sparked by a report by the Information Technology Association of America (ITAA), which predicted a crippling shortage of skilled IT workers, businesses and the U.S. government have expressed concern about the ability of the nation's workforce to meet the heightened demand for IT workers. Predictably, the ITAA report introduced a political dimension and generated considerable interest in the state and nature of the IT workforce and spawned several studies. Each concluded that an adequate supply of qualified IT workers is vital to the U.S. economy. This sentiment was captured by Lester Thurow, "In the twenty-first century, the education and skills of the workforce will end up being the dominant competitive weapon" (Thurow, 1992). The breadth of the gap between IT workforce supply and demand was less clear. Studies tended to concede that the IT industry is diverse and complex and further research was necessary to define the problem effectively.

The U.S. Department of Commerce's Office of Technology Policy explored the issue and issued a report, America's New Deficit: The Shortage of Information Technology Workers, concluding that more information was needed. Subsequently, the U.S. General Accounting Office report evaluated the Department of Commerce report and issued its own report finding that "although the title implied that the Department of Commerce found a shortage of IT workers, data and analysis contained in the report did not support that conclusion (U.S. General Accounting Office, 1998). In fact, the report concluded, and we agree, that more information and data are needed to characterize the IT labor market." A report to the National Academy of Sciences Committee on workforce needs in information technology (Salzman, 2000), found that "exist-

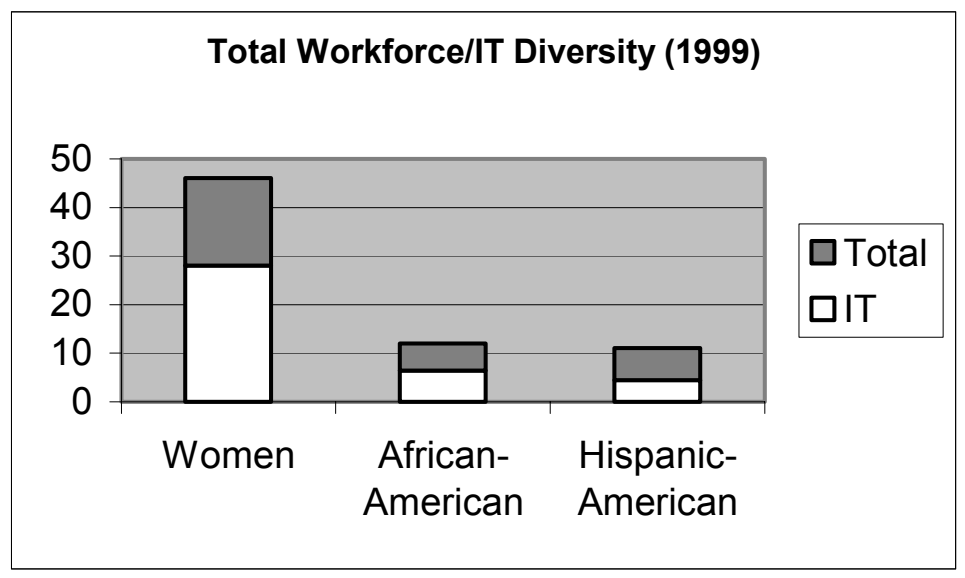

Figure 1. Source: U.S. Bureau of Labor Statistics 
ing data analyses of the IT labor market are not sufficiently detailed to provide an accurate analysis of labor market demand for different segments of the IT industry/workforce - IT is a highly heterogeneous labor market."

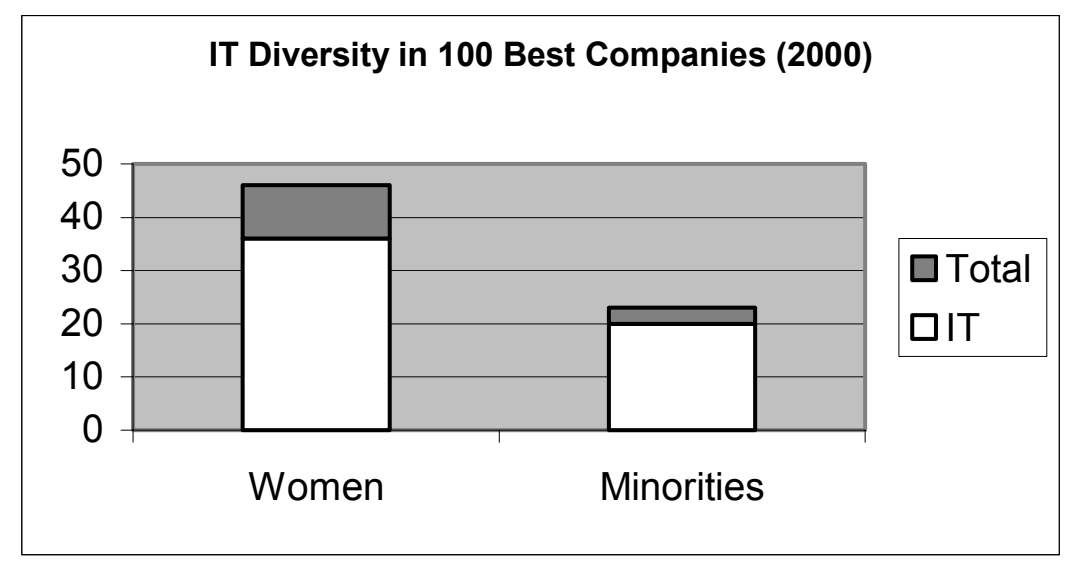

Figure 2. Source: Computerworld

Despite the absence of a comprehensive understanding of the IT labor market three issues are abundantly clear. (1) The demand for IT workers with specific skills is high, as evidenced by low unemployment rates and high growth in total compensation. Between 1987 and 1997 IT unemployment rates closely tracked changes in total unemployment rates, but unemployment rates for all workers were 2 to 3 times greater than for IT workers (U.S. General Accounting Office, 1998). In 2000 the median salary increase for IT workers was 9.2 percent, from $\$ 65,000$ to $\$ 71,000$ (McGee, 2001) compared to the median wage increase for all U.S. workers of 2.9 percent, from $\$ 28,594$ to $\$ 29,413$ (U.S. Bureau of Labor Statistics). (2) A significant number of IT jobs are filled by foreign-born temporary workers. Under the H-1B visa program a foreign citizen may work in the U.S. for up to six years in a professional position that requires specialized training, provided he/she possesses at least a bachelor's degree in the appropriate field or equivalent training or experience and has a business sponsor. The H-1B program was established in 1990 with a cap of 65,000 visas annually. The cap was raised in 1999 to 115,000 and again in 2001 to 195,000 . Under current legislation the maximum number of H-1B visas will return to 65,000 at the end of the 2003 fiscal year. (3) Women, African Americans, and Hispanic Americans are under-represented in the IT workforce. The percentage of the U.S. workforce comprised of women, African Americans and Hispanic Americans has increased over the last decade to 46 percent women, 12 percent African American, and 11 percent Hispanic American. Yet, in 1999 women represented only 28 percent of the IT workforce, African Americans, 6 to 7 percent, and Hispanic Americans, 4 to 5 percent (Figure 1).

From 1989 through 1999 African-American workers in the total workplace remained at 12 percent; the number of Hispanic-American workers increased by 2 percent, from 9 percent to 11 percent; and the number of African-American and Hispanic-American IT workers grew by approximately 1.5 percent each. During this period the number of women in the total workforce increased by 1 percent while the number of women IT workers declined from 30 percent to 28 percent (U.S. Bureau of Labor Statistics).

Computerworld magazine publishes a list of the 100 best companies for IT workers (Computerworld, 2000). The percent of women at the "best" IT companies was 36 percent versus 28 percent overall, and the number of minorities was 20 percent, compared to 12 percent overall (Figure 2).

To identify the best companies the Computerworld survey considered factors that are recognized as barriers to increased diversity in the IT workforce. Benefits, such as childcare and flextime may help women balance the demands of career and family. Women and minorities in management positions may serve as 
Encouraging Minority Enrollment

role models, mentors, and when functioning as hiring-managers, reduce the impact of white, male managers who may hire people they believe will "fit in" best in IT. (Pearl, et al, 1990; House, 2001)

\section{Europe, Asia, Canada and Australia}

The United States is not alone in its concern about the ability of its workforce to meet the demands of the rapidly growing IT workplace. The Institute for Employment Studies reported that "Europe's prosperity is at risk if its supply of graduate science and technology skills does not meet market needs," and noted that "research revealed fundamental problems in the available data about the supply and demand for these skills, which are central to the economic performance of Europe" (Institute for Employment Studies, 2001).

Canada's IT sector has been growing by 10 percent annually; the Indian software industry has been growing by over 40 percent per year; and Malaysia's economic development strategy is based on information technology through development of a "multimedia super corridor." At the same time a survey of 1,500 chief information officers in 21 countries conducted by Deloitte and Touche Consulting Group reported that IT managers worldwide are confronting both high demand for IT workers and high turnover. Turnover rates of 35 to 45 percent were reported for employees experienced in client/server architecture, data modeling, distributed databases, and SAP packaged software (America's New Deficit, 1997).

In the UK, the number of IT jobs increased by 50 percent over the last five years creating 336,000 jobs compared to an 8 percent growth in the general workforce. Yet, only 22 percent of IT workers are women, a decrease of 7 percent from 1994 (Swinton, 2001). Networking, which is recognized as among the fastest growing job specialties, is also viewed as among the most technical. At the end of 2000 only 5.6 percent of network engineers in Western Europe were women, but that number is expected to increase to 7.3 percent by 2005. By 2004, France is projecting women to comprise 12 percent of the networking workforce, the highest percentage of women working in the networking industry of 13 countries surveyed (Mayfield, 2001). Australia's experience has been likewise skewed. While the participation of women in the workforce increased dramatically over the past two decades, the percentage of women in IT declined.

Further, studies suggest that "women are concentrated in lower-paid job categories, such as data entry and computer operator and rarely found in top level positions" (vonHellens and Nielsen, 2001). Around the globe, nations are struggling to understand the complexities of the high-technology workplace and align the output of higher education with industry demand for highly trained workers.

\section{IT Industry and Post-secondary Education}

Several studies have recognized increasing the number of women, African Americans, and Hispanic Americans enrolled in university computer science programs as an important factor in expanding IT workforce diversity (Pearl et al, 1990; Information Technology, 1998; Franz, 2001). The level of minority enrollment in IT degree programs and the role of participatory organizations in increasing minority enrollment are of particular interest to this research.

\section{Higher Education}

\section{Overview of Participation of Women and Minorities in U.S. Science and Engineering Education}

Since 1982, the National Science Foundation (NSF) has produced a series of congressionally mandated biennial reports documenting the participation of women and minorities in the sciences and engineering, including computer science. According to the most recent version of this report (NSF, 2000), women and minorities represent substantially higher proportions of the United States population (Table 2), than they 
do of those completing science or engineering degrees (Table 3). In particular, women, who represent approximately half of the U.S. population, account for 47 percent of the bachelor's degrees and 33 percent of the doctorates in science and engineering. African Americans, approximately 12 percent of the population, account for 7.5 percent of the bachelor's degrees and 3 percent of the doctorates in science and engineering. Hispanic Americans account for 11 percent of the population, but just 6 percent of the bachelor's degrees and 4 percent of the doctorates granted in science and engineering. The following four sections of this report examine the participation of women, African Americans and Hispanic Americans in higher education by summarizing the data in the latest NSF report (2000). Unless otherwise noted, all data in these four sections is from this report.

\begin{tabular}{|l|l|l|l|l|l|}
\hline & \multicolumn{4}{l|}{ Age } \\
\hline & 15 to 19 & 20 to 24 & 25 to 29 & 30 to 34 & 35 to 39 \\
\hline Women & $48.5 \%$ & $48.7 \%$ & $49.8 \%$ & $50.1 \%$ & $50.1 \%$ \\
\hline African American & $14.8 \%$ & $14.1 \%$ & $13.1 \%$ & $12.6 \%$ & $12.0 \%$ \\
\hline Hispanic American & $13.5 \%$ & $14.7 \%$ & $13.6 \%$ & $12.8 \%$ & $10.7 \%$ \\
\hline
\end{tabular}

Table 2. Percentage of US population in various age ranges corresponding to various minority groups (NSF, 2000)

\begin{tabular}{|l|l|l|l|l|}
\hline & \multicolumn{4}{|l|}{ Degree } \\
\hline & Associate's & Bachelor's & Master's & Doctorate \\
\hline Women & $31.0 \%$ & $47.0 \%$ & $39.0 \%$ & $33.0 \%$ \\
\hline African American & $9.1 \%$ & $7.5 \%$ & $14.3 \%$ & $3.0 \%$ \\
\hline Hispanic American & $8.2 \%$ & $6.0 \%$ & $17.7 \%$ & $4.0 \%$ \\
\hline
\end{tabular}

Table 3. Percentage of degrees in science and engineering granted to various groups (NSF, 2000)

\section{Women in U.S. Engineering and Science Education}

Overall, the percentage of women who become college students and who complete bachelor's, master's and doctoral degrees in science and engineering has been increasing. Further, women are more likely than men to attend college, and as likely as men to complete a degree program. The percentage of bachelor's degrees granted to women has risen to close to their percentage in the general population. Since at least 1966, women have earned more than half of all bachelor's degrees in fields outside science and engineering, and women earn almost half of all science and engineering degrees. However, female participation tends to center in certain sciences, like biology, and the percentage and number of computer science bachelor's degrees granted to women has actually declined. In 1984, women earned 37 percent of the bachelor's degrees in computer science. However, by 1996, they were earning just 28 percent of those degrees.

At the master's level, women earn a much smaller percent of the master's degrees in science and engineering fields than they do of the bachelor's degrees in these fields, despite the fact that in other fields women earn approximately the same percentage of master's degrees as they do of bachelor's degrees. Women's science and engineering master's degrees are concentrated in fields such as psychology, the social sciences, and the biological/agricultural sciences. This pattern continues at the doctoral level. Although both the number and percentage of women earning doctoral degrees in science and engineering has risen 
steadily, women still earn far fewer doctorates in science and engineering (33 percent in 1997), than they do in other fields (54 percent). This is despite the fact that by 1999, girls represented 45 percent of the winners of the Intel Science Talent Search (formerly the Westinghouse Science Talent Search), and that girls won the 1999, 2000 and 2001 contests (NCRW, 2001). Further, women who earn Ph.D.s and choose careers in academia do not appear to progress as well as men. "Less than ten percent of full professors in the sciences today are women, despite the fact that women have been earning more than one-quarter of the Ph.D.s in science for thirty years" (NCRW, 2001).

\section{African Americans in U.S. Engineering and Science Education}

As noted earlier, African Americans earn a relatively small percentage of degrees, compared to their percentage of the United States population as a whole. They remain less likely than Whites to complete a bachelor's degree in any field within five years of matriculation. However, the number of African Americans receiving degrees in science and engineering fields is increasing. African American's science and engineering degrees are more concentrated in some fields than in others. In particular, African Americans have been earning higher percentages of undergraduate degrees in computer science, psychology and the social sciences than they did in other sciences and engineering fields. At the master's level, 54 percent of the science and engineering degrees earned by African Americans were in the social sciences and psychology, compared to 40 percent for the population as a whole. At the doctoral level, 37 percent of the doctorates earned by African Americans were in education, compared to 18 percent for the population as

a whole. While the number of doctoral degrees in science and engineering awarded to African Americans is rising, half of the science and engineering doctorates earned by African Americans were in psychology and the social sciences, compared with 32 percent for the general population.

\section{Hispanic Americans in U.S. Engineering and Science Education}

Hispanic Americans earn a relatively smaller percentage of degrees at all levels compared to their percentage of the population as a whole. They remain less likely than Whites to complete a bachelor's degree in any field within five years of matriculation. However, the number of Hispanic Americans receiving degrees in science and engineering is increasing and the degrees are spread across scientific and engineering fields, with the exception of agricultural, earth, atmospheric, and ocean sciences.

\section{African-American and Hispanic-American Women in U.S. Education}

Within minority groups, women appear to be making greater educational gains than men. AfricanAmerican and Hispanic-American women earned a higher percentage of both the associate's and bachelor's degrees granted to their racial and ethnic group than men. In the sciences and engineering, women earned 56 percent of the master's degrees conferred on African Americans. Further, while the number of master's degrees in computer science has been dropping for both male and female Whites, it has increased for African- American and Hispanic-American women.

\section{Women in U. S. Computer Science Education}

As noted in the section on women in science and engineering education, the number of women earning computer science degrees is particularly disappointing. According to Davies and Camp (2000), "CS continually loses women at all stages of the pipeline including elementary, middle and high schools, college, graduate school and beyond." The American Association of University Women (AAUW) notes "Girls who take computer classes take data entry, while boys take advanced programming. Only 17 percent of students who take the computer science Advanced Placement test are girls" (AAUW, 2001). While in 1984, women earned 37 percent of undergraduate computer science degrees; they earned less than 20 per- 
cent of CS degrees in 1999 (NCRW, 2001). One potential reason for the lack of women in computer science and computer engineering degree programs may be the lack of women on computer science faculties. "Women hold fewer faculty positions in CS and CE Ph.D.-granting departments than would be expected by the percentage of doctorates they receive" (Leveson, 1990). Some have postulated that this is due in part to "a pervasive bias against women in refereeing of papers, assessment of professional accomplishments, and teaching evaluations" (O'Leary, 1999). While the full set of reasons for the lack of participation by women in computer science education is beyond the scope of this paper, it is clear that "Over the past twenty years, the student population in Computer Science departments has become increasingly male, and the number of women among faculty members has remained quite small. Thus, many academic Computer Science Departments are almost exclusively male environments" (O'Leary, 1999).

Carnegie Mellon University (CMU) increased the percentage of women undergraduate computer science majors from 7 percent in 1995 to about 38 percent in 1999 (Blum, 2001). This was a result of a concentrated effort to understand and address problem areas in attracting and retaining women students. The five areas that CMU addressed were experience gaps, confidence doubts, the curriculum and pedagogy, and peer culture. In 1999 the Women@SCS Advisory Council was created to build a support community to address some of these areas. Community-building and networking events include student-faculty dinners, undergrad-graduate student dinners, a Big Sister/Little Sister program, dessert socials during exam periods and group outings (Blum, 2001).

\section{A Case Study - DePaul University}

\section{Faculty}

DePaul University's (Chicago, Illinois USA) College of Computer Science, Telecommunications and Information Systems (CTI) currently has 80 full-time faculty members. Sixteen women, three AfricanAmerican men and one Hispanic-American man comprise 25 percent of the total full-time faculty. There are no women of color. In 1995 there were 29 full-time faculty members. Women faculty members represented ten percent of the total number of faculty. There were no African-American or HispanicAmerican faculty members in 1995 . The current faculty represent a 276 percent increase in the total number of full-time faculty members and a 533 percent increase in women faculty members. This significant increase in women faculty members and the addition of African-American and HispanicAmerican faculty members is a result of the concerted effort by the Dean of CTI to recruit and retain these minority segments.

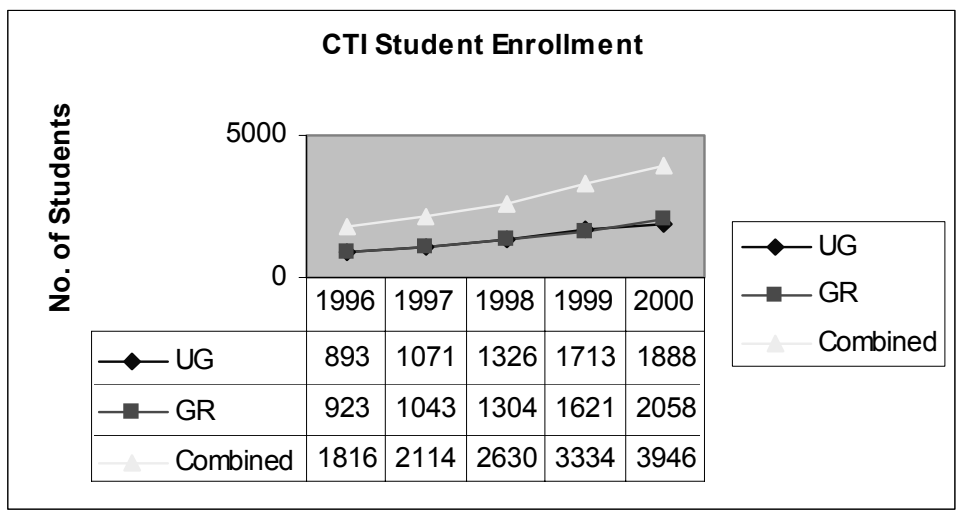

Figure 3. Source: DePaul University (2001)

\section{General Enrollment}

Enrollment in CTI increased over 217 percent between 1996 and 2000. The increase was evenly split between both undergraduate and graduate students (Figure 3 ).

\section{Enrollment of Women Students}

During that same time period, the number of women enrolled in CTI increased only slightly (Figure 4). Undergraduate and graduate women students increased at almost the same percent. The total number of women enrolled at CTI in 2000 was 1,421 
Encouraging Minority Enrollment

students.

\section{Enrollment of African-American Students}

The number of African-American students has decreased slightly, approximately 2 percent, with an almost 5 percent decrease in undergraduate students and less than 1 percent increase in graduate students (Figure 5). The total number of African-Americans enrolled at CTI in 2000 was 356 students.

\section{Enrollment of Hispanic-American Students}

The total number of enrolled Hispanic-American students has seen a similar decrease, approximately 1 percent. However, the undergraduate students increased, less than 1 percent while the decrease in graduate students was slightly higher than 2.5 percent (Figure 6). The total number of Hispanic Americans enrolled at CTI in 2000 was 271 students.

Although DePaul CTI's general enrollment is increasing, there is no significant percentage increase in women while the percentage of African-American and Hispanic-American enrollment has slightly decreased over the last five years.

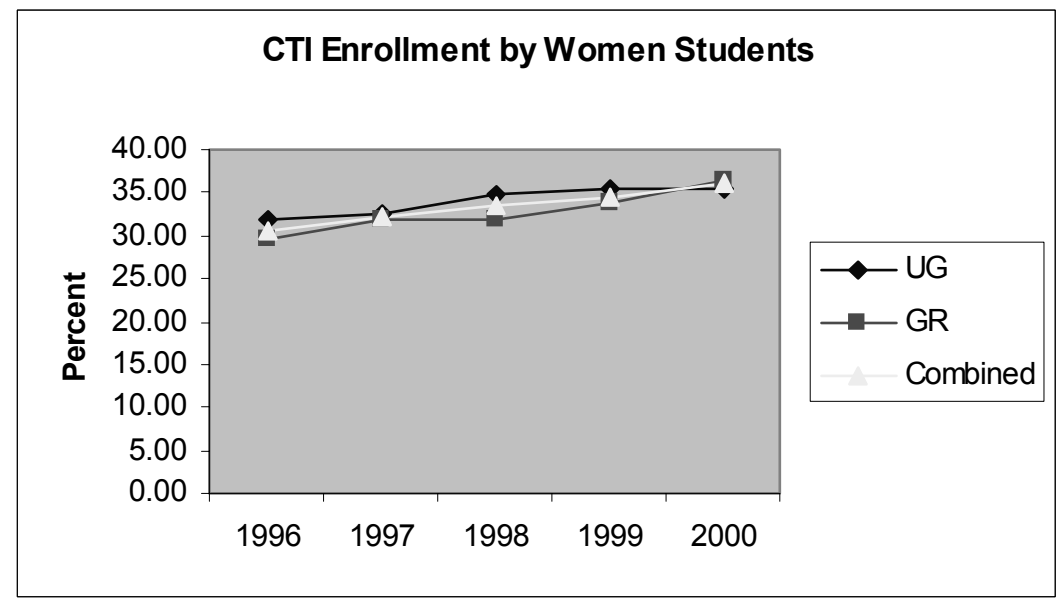

Figure 4. Source: DePaul University

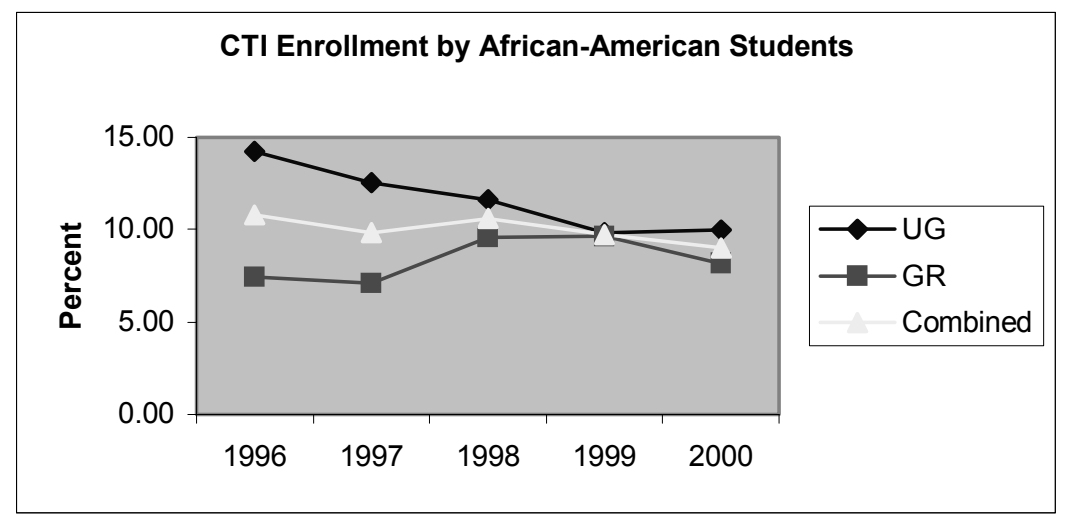

Figure 5. Source: DePaul University

\section{Participatory Organiza- tions at DePaul CTI}

\section{Computer Science Society}

The Computer Science Society was created in September 1996 by three students "to create an atmosphere for learning, and set goals for transforming the students at CTI into the IT professionals of the future" (http://clinton.cs.depaul.edu/css/). Recent activities have included researching companies, participation on project teams developing applications, and organizing future events such as employer recruiting nights and tutorials on developer software. The majority of students involved in the organization are male undergraduate students and the leadership team has been exclusively White and Asian males since its inception. 


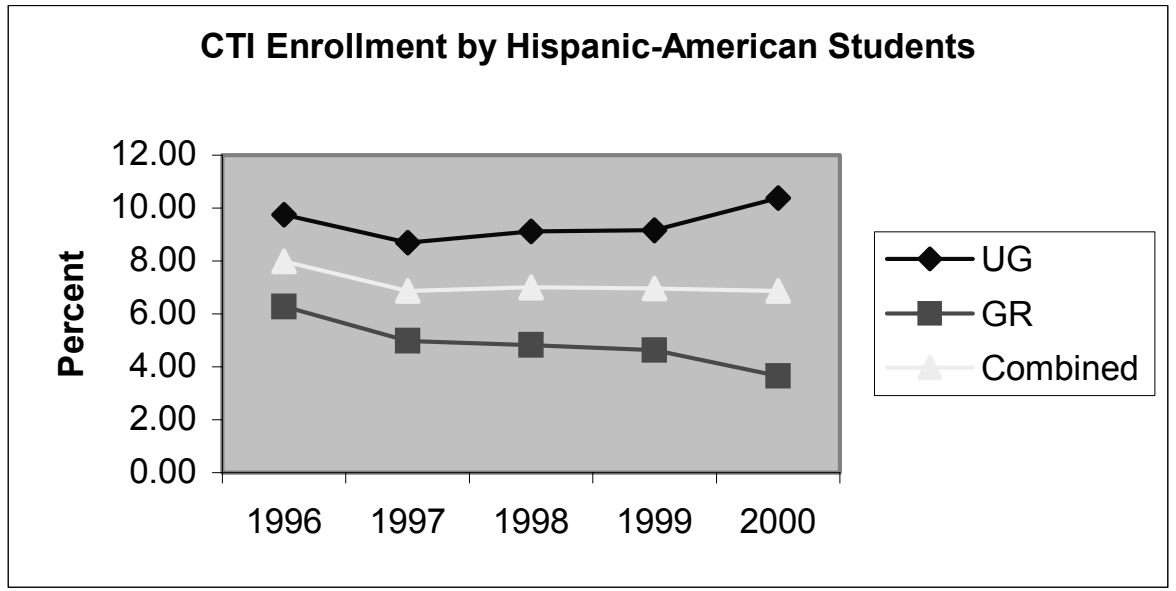

Figure 6. Source DePaul University

\section{DePaul Chapter of ACM-W}

During the Winter and Spring quarters of academic year 2001, it was noted by some DePaul CTI women faculty members that there did not appear to be a proportionate increase of women students in individual classes when compared to the explosive growth overall in CTI. In August 2001, a woman faculty member, who would late become the inter-

nal champion for women CTI students, attended a regional conference sponsored by the Women's Bureau, Region V of the U.S. Department of Labor, "Expanding the Pipeline: Women \& Girls in Science, Engineering \& Technology," in Chicago, Illinois USA. The goal of this conference was to promote career and education opportunities for women and girls. Women from universities, secondary educational facilities, and industry representatives from the Midwest were chosen as panelists to discuss their organization's experiences, as well as to share personal recollections. The faculty champion gathered further information on women-participatory organizations through a search of the World Wide Web. Sites that were reviewed for ideas, inspiration and organization included:

- Association for Computing Machinery: Committee on Women in Computing http://www.acm.org/women).

- Association for Women in Computing http://www.awc-hq.org/

- Association for Women in Science http://www.awis.org/

- Center for Women and Information Technology, University of Maryland Baltimore County http://www.umbc.edu/cwit/

- Computing Research Association http://cra.org/Activities/craw/

- Institute for Women and Technology http://www.iwt.org/home.html

- Institute of Electrical and Electronics Engineers (IEEE) Women in Engineering http://www.ieee.org/organizations/committee/women/

- Society of Canadian Women in Science and Technology http://www.harbour.sfu.ca/scwist/

- Society of Women Engineers http://www.swe.org/

- Women in Science, Engineering and Technology: Sheffield Hallam University http://www.shu.ac.uk/witec/

- Women in Technology International http://www.witi.org/center/

The faculty champion planned an exploratory meeting to gauge the interest of DePaul CTI women students in forming a support community. A request was made asking that an invitation be sent to all women students through the college's email system. Due to the conversion of the internal, homegrown information system to an Enterprise Resource Planning system, an email distribution list could not be created by gender. Subsequently, an invitation was placed on DePaul CTI's Web home page, and eight 
Encouraging Minority Enrollment

women faculty members announced the meeting in their classes. These announcements were made in primarily undergraduate courses. The first two meetings were held in October and November 2001. Fifteen graduate students and one undergraduate student attended the meetings. The graduate student turnout was particularly strong, considering the meeting had been announced in only two graduate classes. There was general consensus among the participants that this chapter was needed to provide peer support, opportunities for networking, promotion of university programs and research opportunities, skills assessment, tutoring, employment prospects and personal exploration such as stress reduction techniques and balancing career, education and life. The faculty sponsor made the decision to be affiliated with the Association for Computing Machinery (ACM) for two reasons. First, ACM is the world's oldest and largest educational and scientific computing society. ACM serves a membership of more than 80,000 computing professionals in more than 100 countries in all areas of industry, academia, and government

(http://www.acm.org). Second, the ACM recently formed a Committee on Women in Computing (ACM$\mathrm{W})$ whose mission is to engage in activities and projects that aim to improve the working and learning environments for women in computing. This includes promoting activities that result in more equal representation of women in computer science such as (http://www.acm.org/women):

- mentoring or role modeling;

- monitoring the status of women in industrial and academic computing through the gathering of statistics;

- providing historical information about women's accomplishments and roles in CS;

- serving as a repository of information about programs, documents and policies of concern to women in CS.

A sponsored project is the development of a model for creating an ACM-W Student Chapter. The formation of ACM-W student chapters began in 2001 and can be found at:

- University of South Alabama (Mobile, Alabama USA)

- Texas A \& M University (Station, Texas USA)

- Utah State University (Logan, Utah USA)

- Furman University (Greenville, South Carolina USA)

- Central Indiana - Depauw University (Greencastle, Indiana USA)

The petition for chapter membership of the "DePaul Chapter of ACM-W" was submitted in December 2001. A kick-off event is planned for February 2002. The Director of the Department of Labor Women's Bureau, Region V will be speaking about employment in the IT sector, a Vice President of IT will discuss the CIO's viewpoint, an employment specialist from Chicago will discuss IT opportunities in the area and a representative from DePaul's Career Center will discuss the resources available through the university. A Web site was developed (http://clinton.cs.depaul.edu/acmw/) to promote the chapter as well as email to all women graduate and undergraduate students, faculty and alumni. Other events planned for the academic year include tutorials on Java programming, Unix, presentation and writing skills.

\section{National Society of Black Engineers}

The National Society of Black Engineers (NSBE) invited DePaul University to their 2000 Region IV conference to promote the university to NSBE members. One of the three African-American male, full-time faculty members was asked to represent DePaul. NSBE has more than 270 collegiate, 75 professional and 75 pre-college chapters nationwide and overseas with more than 10,000 members. It is the largest student-managed organization in the country (http://www.nsbe.org). NSBE's mission is to increase the num- 
ber of culturally responsible black engineers who excel academically, succeed professionally and positively impact the community. The objectives of the organization are to:

- stimulate and develop student interest in the various engineering disciplines;

- strive to increase the number of minority students studying engineering at both the undergraduate and graduate levels;

- encourage members to seek advanced degrees in engineering or related fields and to obtain professional engineering registrations;

- encourage and advise minority youth in their pursuit of an engineering career;

- promote public awareness of engineering and the opportunities for African Americans and other minorities in that profession;

- function as a representative body on issues and developments that affect the careers of black engineers.

NSBE has more than 260 student chapters throughout the USA and nine student chapters in Canada. The International Committee (IC) of NSBE has been charged with expanding and maintaining NSBE's global mission through the establishment of chapters in Africa, Europe, South America, the Caribbean, Australia, the Pacific Islands and Asia. International Conferences have been held in 1998 (Ghana), 1999 (Ghana) and 2000 (South Africa, Zimbabwe). The next conference will be held in Jamaica in the summer of 2002.

After attending the conference, the faculty champion believed if a student chapter were formed at DePaul CTI the currently enrolled African-American students would have a higher success rate and therefore a higher retention rate. Many African-American students at DePaul CTI have a non-technical background, which increases their stress level in technical courses. Email was sent to all enrolled African-American students in CTI announcing the formation of the chapter. Thirty-seven students were at the initial meeting of which the majority were women graduate students. Women filled the four leadership positions. The program for the first year focused on promoting peer support among the students. It was envisioned that graduate students would act as role models/mentors for undergraduate students since the majority of CTI graduate students are professionals working in industry.

\section{Society of Hispanic Professional Engineers}

The success of the NSBE chapter led the faculty champion to believe that a similar organization geared toward Hispanic Americans would also be beneficial to retaining Hispanic-American students at DePaul CTI. CTI currently has only one full-time Hispanic-American faculty member. He was recruited to be the faculty sponsor in September 2001. The founding meeting was held in October and attracted almost fifty students. They are currently in the process of chapter organization and recognition by the Society of Hispanic Engineers (SHPE) and are working on the program and Web site for the current academic year.

SHPE was founded in Los Angeles, California, in 1974 by a group of engineers employed by the city of Los Angeles (http://www.shpe.org/). Their objective was to form a national organization of professional engineers to serve as role models in the Hispanic community. The concept of networking was the key basis for the organization. The organization promotes:

- statement of values: We are brought together by heritage, social responsibility and desire to improve the equality of all people through the use of science and technology. We value excellence in education, professional pursuits and leadership. We obtain excellence through integrity, empowerment, achievement, diversity and continuous improvement; 
Encouraging Minority Enrollment

- vision: SHPE is the leading social-technical organization whose primary function is to enhance and achieve the potential of Hispanics in engineering, math and science;

- mission: SHPE promotes the development of Hispanics in engineering, science and other technical professions to achieve educational excellence, economic opportunity and social equity;

- strategic focus areas: We will fulfill our mission by increasing educational opportunities, promoting professional and personal growth, carry out our social responsibility to be involved in education, business and government issues and enhancing pride within our organization and reinforcing our reputation as a vital Hispanic organization.

\section{Discussion}

It is anticipated that these three participatory organizations will help retain student enrollment in these population segments of the university. However, these chapters are in their infancy and results may not be realized for a few years. Nonetheless, DePaul CTI's experience in initiating these student chapters does provide a list of critical success factors for others seeking to begin similar student organizations:

- Administrative vision and support. Strong administrative support from the Dean of CTI has been critical to the success of the formation of these chapters. He has provided monetary support, space for meetings and activities, resources of the university such as server space, and permission to access current student and alumni email addresses, in addition to the moral leadership and vision that have helped make these societies a reality.

- Enthusiastic faculty champion. The source of initiation of the chapters, whether it is administration or faculty, is not important. It is crucial that the faculty sponsor be willing to devote time and energy to the formation of the chapter as well as transition periods between leadership teams. Faculty sponsors who are halfhearted result in organizations that lack both growth and continuity.

- Relevant activities. These chapters will only be successful if interesting and relevant activities draw the target segment together to provide peer support and networking opportunities. Without any prompting from the sponsor, the members of the DePaul Chapter of the ACM-W quickly compiled a list of activities that addressed their needs to be successful in their educational, professional and personal goals.

- Willing leaders. These chapters are designed to be student-led. They provide students an opportunity to learn and practice their team and leadership skills.

- Ability to reach the target audience. It is crucial in the formation stages to reach the largest number of potential members. Accessibility to women student email accounts was an initial problem for the DePaul Chapter of the ACM-W.

- Identification of a convenient meeting time. At DePaul CTI, the majority of the women graduate students are professionals with a workday that generally ends at 5:00 p.m., with graduate classes meeting at 5:45 p.m. Monday through Thursday. Many of these students also have family responsibilities. Although NSBE and SHPE have successfully scheduled their meetings and events for Saturday mornings, the graduate women were not interested in Saturday morning meetings and settled upon Friday evenings at 5:45 p.m. The lesson to be learned is that it is crucial to select an initial meeting likely to be convenient for most members of the target audience, and allow the students to determine a meeting schedule that works best for them. 


\section{Conclusion}

As in the past, the IT industry will continue to require an increasing number of qualified workers. Women, African Americans and Hispanic Americans are an under-represented segment of the IT workforce. Studies have shown that increasing the enrollment of this population in university computer science programs will be important in meeting the demand for qualified IT professionals. One method of achieving these results is through positive peer culture, specifically through the organization of support communities.

DePaul CTI has sponsored three student-led chapters - DePaul Chapter of ACM-W, National Society of Black Engineers and Society of Hispanic Engineers - to help retain student enrollment in these underrepresented segments of the university and IT workforce. DePaul CTI's initial experience indicates that, in addition to a supportive administration, a faculty champion is critical for each group to succeed. The actual impetus for the organization may come from either students or faculty, but it is important that the faculty champion serve primarily as a facilitator, allowing students to set the organization's agenda. This not only provides students with leadership opportunities, but also insures that the organization will meet the needs of the target student population.

\section{References}

Anonymous. (June 5, 2000). 100 Best Places to Work in IT. Computerworld.

AAUW Public Policy and Government Relations Department. (2001, January). Gender equity in education: myth vs. reality. Retrieved November 26, 2001 from the World Wide Web at http://www.aauw.org/1000/pospapers/geiebd.html

Barinaga, M. (1994, March 11). Surprises across the cultural divide. Science, 1468-1472. Retrieved December 6, 2001 from the World Wide Web http://onlineethics.org/scsel/abstracts/surpcultdiv.html (Abstract by Midgley, J.)

Blum, L. (2001, November 2). Transforming the culture of computing at Carnegie Mellon. Retrieved December 6, 2001 from the World Wide Web http://www-2.cs.cmu.edu/ lblum/TransformingTheCulture.pdf

DePaul University Demographic Characteristics of Students. Retrieved December 6, 2001 from the World Wide Web http://oipr.depaul.edu/open/factfile/2000/sect2/sect2.asp.

Fain, J. (1999, January). Ranking the factors that affect occupational outcomes. Industrial Relations, 38(1), 92-105.

Franz, R. (2001) “Anti-Affirmative (Re) Action” Retrieved December 6, 2001 from the World Wide Web http://www.graduatingengineer.com/articles/minority/05-01-01/html.

House, T. (2001, May 14). "Equal IT Hiring a Must". Computerworld.

The Institute for Employment Studies. (2001, March 12). Europe Needs a Science and Technology Skills Observatory.

ITAA. (1997). The IT Workforce Gap at the Dawn of a New Century, , Arlington Va

Leveson, N.G. (1990, July). Educational pipeline issues for women. Panel presentation at CRA Snowbird meeting. Retrieved November 26, 2001 from the World Wide Web http://www.mills.edu/ACAD_INFO/MCS/SPERTUS/Gender/pipeline.html

Mayfield, K. (2001, December 1). "IT: The Industry Without Women,” Wired News.

McGee, M. K. (2001, April 30) Informationweek.com "Salary Strongholds".

National Society of Black Engineers. Retrieved December 6, 2001 from the World Wide Web http://www.nsbe.org

NCRW National Council for Research on Women. (August 8 2001). Balancing the equation; What we know and what we need. Retrieved December 6, 2001 from the World Wide Web http://www.ncrw.org/research/scifacts.htm

NSB National Science Board (1998). Science and engineering indicators. Retrieved December 5, 2001 from the World Wide Web http://www.nsf.gov/sbe/srs/seind98/

NSF National Science Foundation (2000, September). Women, Minorities, and Persons with Disabilities in Science and Engineering. Retrieved December 6, 2001 from the World Wide Web http://www.nsf.gov/sbe/srs/nsf00327/pdf/document.pdf 
Encouraging Minority Enrollment

O'Leary, D.P. (1999, June 2). Accessibility of computer science: A reflection for faculty members. Retrieved December 6, 2001 from the World Wide Web http://www.cs.umd.edu/users/oleary/faculty/whole.html

Pearl, A., Pollack, M. E., Riskin, E., Thomas, B., Wolf, E., Wu, A. "Becoming a Computer Scientist: A Report by the ACM Committee on the Status of Women in Computing Science," Communications of the ACM November 1990 33:11 47-58.

Salzman, H. The Information Technology Industries and Workforces: Work Organization and Human Resource Issues. Center for Industrial Competitiveness/University of Massachusetts, November 2000

Society of Hispanic-American Professional Engineers. Retrieved December 6, 2001 from the World Wide Web http://www.shpe.org/

Swinton, A., “Government Calls for More Women in IT,” ZDNet UK News. October 18, 2001.

Thurow, L., Head to Head: The Coming Economic Battle Among Japan, Europe, and America. New York: Marrow and Co., 1992.

United States Government Accounting Office, Washington DC. (1998). Information Technology :Assessment of the Commerce Department's Report on Worker Demand and Supply.

U.S. Department of Commerce, Office of Technology Policy. (1997, September). America's New Deficit: The Shortage of Information Technology Workers.

Von Hellens, L. and Nielsen, S. “Australian Women in IT, Communications of the ACM. 44,7: July 2001, 46-52.

\section{Biographies}

Theresa A. Steinbach is an Instructor at DePaul University's School of Computer Science, Telecommunications and Information Systems. She teaches Web-based scripting as well as teaching and conducting research in traditional and e-commerce systems analysis and design. Ms. Steinbach is founder of the student-led DePaul Chapter of the Association for Computing Machinery-Women as well as the faculty sponsor. As owner of an IT consulting firm, she provided turnkey solutions for small and medium size enterprises. Ms. Steinbach is currently completing her Ph.D. in Computer Science from DePaul University. She holds a B.A. in Mathematics, an M.B.A in Quantitative Economics and an M.S. in Information Systems from DePaul University.

James D. White is an Instructor at DePaul University's School of Computer Science, Telecommunications and Information Systems. He teaches undergraduate and graduate Information Systems courses as well as conducting research in the strategic use of applications, and systems analysis and design. Prior to joining DePaul, Mr. White held the position of Vice President - Information Systems for the Chicago Board of Trade with hiring authority for over ninety IT positions. He received a B.A. in Psychology from Northwestern University, an M.B.A. from Dominican University and is currently completing his Ph.D. in Computer Science at DePaul University.

Linda V. Knight is Associate Dean of DePaul University's School of Computer Science, Telecommunications, and Information Systems. She is also Director of CTI's Center for the Strategic Application of Emerging Technologies. Co-developer of one of the world's largest e-commerce degree programs, she lectures on the topic of e-commerce curricula and teaches and conducts research in the area of ecommerce business strategy, development, and implementation. She is Associate Editor of the Journal of IT Education, and serves on the Editorial Review Board of the Information Resources Management Journal. An entrepreneur and IT consultant, she has held industry positions in IT management and quality assurance management. She holds a PhD in Computer Science from DePaul University. 